\title{
Hepatitis B: Where Are We Today?
}

\author{
Volker Eckert ${ }^{\mathrm{a}} \quad$ Wilhelm G. Struff ${ }^{\mathrm{b}}$ \\ a Roßdorf, \\ ${ }^{b}$ German Red Cross BTS Northrhine-Westfalia, Münster, Germany
}

\section{Key Words}

Hepatitis B - Geographic distribution - Life cycle .

Antigens · Mutants · Resistance

\section{Summary}

Hepatitis B still is a major challenge of modern medicine. Here, we summarize the disease, the life cycle of the virus, the emergence of drug-resistant mutant strains and resulting consequences for new drug development. Hepatitis $B$ has a worldwide prevalence of $0.1-20 \%$. It occurs in an acute and a chronic phase. The acute phase is characterized by viral replication, onset of immune response leading to destruction of infected hepatocytes and, in most cases, viral clearance and lifelong immunity. Clinical symptoms are observed in this phase. The chronic phase is characterized by lifelong persistence of the virus, often without clinical symptoms but bearing the risk of hepatic cirrhosis or hepatocellular carcinoma. Both phases are distinguished by detection of viral antigens and hepatitis $B$ antibodies in the blood. The hepatitis $B$ virus (HBV) shows several features unique for hepadnaviridae: i) formation of covalently closed-circle DNA (cccDNA) as template for viral DNA replication and synthesis of viral RNAs and ii) a reverse transcription step in the synthesis of new viral DNAs. These features are the prime targets in antiviral drug development. Unfortunately, with the exception of interferon, resistant mutant strains of HBV were found after widespread use of every new drug so far. Therefore, combination therapies aimed at different targets are being discussed so that the selective pressure can no longer be compensated by HBV. This paper is the first part of a trilogy concerning HBV which will also discuss the situation regarding transplantation (second part) and blood transfusion (third part).

\begin{tabular}{ll}
\hline KARGER & @ 2006 S. Karger GmbH, Freiburg \\
Fax +497614520714 & Accessible online at: \\
$\begin{array}{l}\text { E-mail Information@Karger.de } \\
\text { www.karger.com }\end{array}$ & www.karger.com/tmh
\end{tabular}

\section{Schlüsselwörter}

Hepatitis B · Geographische Verteilung · Lebenszyklus ·

Antigene $\cdot$ Mutanten $\cdot$ Resistenz

\section{Zusammenfassung}

Hepatitis B ist nach wie vor eine der größten Herausforderungen der modernen Medizin. Wir geben einen Überblick über die Erkrankung, den Lebenszyklus des Virus, das Auftreten von Resistenzmutationen und die daraus resultierenden Konsequenzen für die Entwicklung neuer Medikamente. Hepatitis B tritt weltweit mit einer Prävalenz von 0,1-20\% auf. Die Krankheit manifestiert sich in einer akuten und einer chronischen Phase. Die akute Phase zeichnet sich aus durch virale Replikation, Einsetzen der zur Zerstörung befallener Hepatozyten führenden Immunantwort und in den meisten Fällen Eliminierung des Virus und lebenslange Immunität. Klinische Symptome treten gewöhnlich in dieser Phase auf. Die chronische Phase zeichnet sich durch lebenslange Persistenz des Virus aus, oft symptomlos, jedoch mit der Gefahr einer Leberzirrhose oder eines Leberzellkarzinoms. Beide Phasen können durch den Nachweis zirkulierender viraler Antigene sowie Hepatitis-B-Antikörper identifiziert werden. Die Biologie des Hepatitis-B-Virus (HBV) zeichnet sich durch bestimmte Eigenschaften aus, die für die Hepadnaviridae einzigartig sind: 1) Bildung eines kovalent geschlossenen, zirkulären DNA-Strangs (cccDNA) als Matritze für die Replikation viraler DNA und die Synthese viraler RNAs und 2) eine Reverse-Transkriptase-Funktion während der Synthese neuer viraler DNAs. Diese Eigenschaften sind bevorzugte Ziele bei der Entwicklung antiviraler Medikamente. Leider sind bisher bei jedem neuen Wirkstoff (mit Ausnahme von Interferon) nach weitreichendem Einsatz Resistenzmutationen beobachtet worden. Daher werden nun Kombinationstherapien mit unterschiedlichen Angriffspunkten diskutiert, um den Selektionsdruck soweit anzuheben, dass er durch das HBV nicht mehr kompensiert werden kann. Die vorliegende Arbeit ist Teil einer Trilogie, die im zweiten Teil das Gebiet der Organtransplantation und im dritten Teil das Thema Bluttransfusion betrachten will. 


\section{Introduction}

Hepatitis B is still one of the most prevalent communicable diseases worldwide. It is estimated that over 2 billion people alive today have been infected with the hepatitis $B$ virus (HBV) at some time in their lives. Of those, 350 million people are suffering from chronic hepatitis and are persistent HBV carriers and thus one of the main sources of infection. Annually, 1 million deaths are attributed to hepatic cirrhosis, hepatocellular carcinoma and acute liver failure as a consequence of HBV infection [1]. The geographic distribution shows a significant gradient between Western countries and developing nations. It is estimated that in Southeast Asia, China and Africa where prevalence is high, more than half the population are exposed to HBV at some point in their lives, resulting in $8-20 \%$ being chronic carriers. The predominant ways of infection in these areas are perinatal transmission (vertical) or transmission from child to child (horizontal). In areas with low levels of infection (low prevalence), such as North America, Western Europe and Australia, the predominant way of infection is horizontal transmission between young and sexually active adults $[1,2]$. The currently recognized modes of transmission are: i) infected mother to child at birth (perinatal/neonatal), ii) close contact with an infected person, iii) sexual contact, iv) parenteral exposure to blood (blood to blood) or other body fluids or specimens, such as surgical instruments or laboratory equipment $[1,2]$. As HBV serum levels in infected individuals can be very high $\left(10^{8}-10^{10}\right.$ infectious virions/ml) $[1,3,4]$, even invisible traces of serum are a potential source of infection. $\mathrm{HBV}$ is also detectable in semen, saliva, breast milk, urine and cervical discharge [2-4, 162].

Since the discovery of HBV in 1965 by Baruch Blumberg [5], tremendous effort has been put into understanding the virus and the disease caused by it, leading to the successful development of vaccines and a good understanding of the biology and complexity of HBV. Vaccination has proven to be an effective way of protection against HBV infection, as demonstrated by several national vaccination programs [1]. However, in its chronic state, the virus can currently not be eradicated by medical treatment, and there is no specific treatment for acute hepatitis B [6]. In this article we will summarize the current understanding of $\mathrm{HBV}$-induced liver disease and the biology of HBV. We will also focus on current prophylaxis protocols other than vaccination, with emphasis on current developments in antiviral drugs, especially anti-HBV immune globulin (HBIG).

\section{Hepatitis B: Geographic Distribution}

As mentioned above, there is a clear gradient between socalled developed countries and the Third World. Bearing in mind the large number of unreported cases, the prevalence of hepatitis B in the various areas of the world is estimated as follows $[1,7,8]:<2 \%$ in Northern, Western and Central Europe, North America and Australia, with a prevalence of carriers particularly among blood donors in Northern Europe, North America and Australia of $0.1 \%$ or less; $2-8 \%$ in Eastern Europe, the Mediterranean, Russia and the Russian Federation, Southwest Asia, Central and South America; $>8 \%$ in parts of China, Southeast Asia, tropical Africa, with high endemic areas where as many as $20 \%$ of the apparently healthy population may be asymptomatic carriers and thus a huge reservoir of infection. In low-prevalence areas the predominant way of infection is horizontal transmission between young and sexually active adults and members of certain risk groups, such as intravenous drug users. This leads to a mostly acute course of disease with either acute hepatitis, hepatic failure or spontaneous clearance. In high-prevalence areas, infection is acquired neonatally or transmitted from child to child at a very early age. This results in predominantly chronic hepatitis with the consequence of liver failure or liver cancer (hepatocellular carcinoma, HCC) at a later age in a high number of HBV carriers (see below) $[1,4,9]$. Hence, the risk of infection is high in such countries, with consequences in relation to global travel and migration due to war or famine.

Several attempts have been made to eradicate or at least significantly reduce the prevalence of hepatitis by vaccination programs. Initial attempts, e.g. in the USA, were aimed at high-risk groups to prevent the virus from spreading amongst the adult population. The failure of such programs was largely attributed to the lack of compliance of the targeted group, combined with problems in assessing and identifying vaccination candidates [10]. Epidemiological calculations revealed that the only way to reduce the prevalence of hepatitis B in a population is the consequent vaccination of newborns to eliminate the number of chronic carriers and thus the main reservoir of infection [11]. This hypothesis was shown to be correct by the infant vaccination program in Taiwan, dramatically reducing infections in newborns and thus the overall numbers of carriers in the population [12]. The authors describe that in $1982,15-20 \%$ of the general population were carriers of hepatitis B surface antigen ( $\mathrm{HBsAg}$ ). As a consequence, HCC accounted for $20 \%$ of all malignancy-related deaths, and hepatitis-related chronic diseases, such as cirrhosis, caused about $90 \%$ of deaths due to liver diseases, thus putting hepatitis Brelated fatalities at rank 6 of the 10 main causes of deaths in Taiwan [12]. After the vaccination program was initiated in 1982, strictly all newborns were vaccinated. Babies born to high-titer HbsAg-positive mothers are at particularly high risk, with $90 \%$ of such infants becoming chronic carriers without intervention. These infants received a single dose of HBIG at birth in addition to the regular vaccination regimen, a combination which proved to be highly effective in preventing perinatal infection for these high-risk babies [13, 14], thus assuring the success of the vaccination program [12]. This strictly executed program was subsequently shown to have re- 
duced the prevalence of HBsAg to $1.7 \%$ in children aged 6 between 1989 and 1993. If the program is maintained with the same strictness, it is estimated that by the year 2010 the carrier rate in children in Taiwan will have declined to $<0.1 \%[12,15]$. Similar results were reported for the Italian hepatitis B vaccination program $[16,17]$ as well as by a survey of worldwide vaccination programs [18], emphasizing the importance of protecting newborns by vaccination against $\mathrm{HBV}$ to eliminate the prime source of chronic carriers.

\section{Hepatitis B: The Disease}

HBV hepatitis is initiated by infection of hepatocytes with $\mathrm{HBV}$, followed by viral replication and spread of the infection to other hepatocytes (see below). It is important for the understanding of the disease that infection and virus propagation per se does not destroy the hepatocytes. On the contrary, the virus can be maintained and propagated inside hepatocytes for the entire life span of the infected cell. The initial phase of the infection is characterized by a feeling of sickness, fever, weakness, jaundice (rare) and flu-like symptoms, thus making diagnosis difficult. During this acute phase in which infective virions and viral antigens are released into the bloodstream, the patient's immune system initiates an immune response and starts to destroy infected hepatocytes, which in turn elicits the clinical picture of hepatitis with jaundice and elevation of serum transaminases. The liver disease caused by the HBV infection is therefore the result of the host's immune system trying to eliminate infected hepatocytes rather than of direct damage elicited by the virus [19]. This acute form of disease often resolves spontaneously after $4-8$ weeks, with most patients recovering without significant consequences or recurrence. In a number of cases, the disease develops into a fulminant hepatitis with acute hepatic necrosis resulting in death [1, 4, 9, 19, 20].

Acute hepatitis B is characterized by the presence of anti-HBc IgM serum antibodies converting to $\mathrm{IgG}$ during convalescence and recovery, and the transient ( $<6$ months) presence of HBsAg, hepatitis B e antigen (HbeAg) and viral DNA, with clearance of these markers followed by seroconversion to anti-HBs and anti-HBe. During this acute phase, in most adults, the immune system is able to eliminate infected cells and circulating virus, resulting in eradication of the infection and a lifelong immunity [6]. More than $90 \%$ of infections in adults fall into this category. The remaining $5-10 \%$ of adultonset infections and $>90 \%$ of neonatal infections become chronic and can continue for the life span of the patient, with the consequence of hepatic cirrhosis and subsequent liver failure or HCC in the majority of patients. Chronically infected individuals in the carrier state represent the predominant reservoir of infection. The chronic and thus carrier state is defined as persistence of HBsAg in the circulation for $>6$ months $[1,4,6]$. Chronic hepatitis $\mathrm{B}$ is a prolonged infection which generally develops over many years. It is characterized by persistent serum levels of HbsAg and anti-HBc IgG and the absence of an anti-HBs antibody response. HBV DNA and $\mathrm{HBeAg}$ are often detectable at high concentrations, but may disappear if viral replication ceases during the course of the chronic disease. The associated inflammatory liver disease is characterized by varying severity. It is generally milder than acute hepatitis B, however, it usually lasts for decades, progresses to cirrhosis in approximately $20 \%$ of cases and is associated with an up to 100-fold increase in the risk of HCC [4, 21]. In patients with chronic hepatitis $B, 3$ phases of viral replication typically occur during the course of an HBV infection [9]: i) High-replicative phase: $\mathrm{HBsAg}, \mathrm{HBeAg}$ and $\mathrm{HBV}$ DNA are present and detectable in the patient's serum with usually increased aminotransferase levels and moderate, histologically apparent inflammatory activity. ii) Low-replicative phase: this phase is associated with the loss of HbeAg, decrease in or loss of HBV DNA in the patient's serum and appearance of anti-Hbe-IgG. iii) Non-replicative phase: low levels of the viral replication markers HBsAg and HBV DNA may be present. However, the majority of patients with chronic hepatitis B do not progress into the non-replicative phase. Due to the permanent presence of $\mathrm{HBV}$, the regenerating liver parenchyma is constantly reinfected and subsequently destroyed by the host's immune system. Hence, there is a delicate balance between excessive liver destruction (autoaggression with the possibility of a fulminant and thus potentially lethal course of disease), complete clearance of the virus and immunity and failure to eliminate the virus (chronic infection), with the patient's chances of recovery poised between extremes. For patients with chronic hepatitis B, the difference between the chronic persistent and the chronic active course is all-decisive, as the latter may lead to cirrhosis and/or HCC [3, $4,9,22,23]$.

The course of infection as described above varies according to superinfection with other pathogens, the patient's general health and, most important, age. As indicated above, the age of the individual at the point of infection largely determines the course of disease. The risk of chronic infection and thus of becoming an asymptomatic carrier is inversely proportional to age. It is highest for infants who become infected during the perinatal period and lowest for older children and adults. These findings can be summarized as follows [11, 22-24]: i) infection during the perinatal period: acute symptoms in $<5 \%$ of cases, almost exclusively progression to chronic infection and carrier state (70-90\%); ii) infection at the age of $1-5$ years: acute infection in $50-80 \%$ of cases; iii) infection at the age of $>5$ years: predominantly acute hepatitis $(>90 \%)$, with about $5 \%$ of patients developing long-term chronic infections. For the USA it is estimated that only $8 \%$ of acute infections occur between birth and the age of 10 years. However, infection at this age accounts for approximately one third of all chronic infections [25]. Besides becoming a disease carrier, infection at an early age also bears an elevated risk of developing cirrhosis 
or HCC, which is correlated with the length of time a person is chronically infected. Infants who become chronically infected have a lifetime risk of developing cirrhosis or HCC of approximately $25 \%$, whereas for adults acquiring a chronic infection the estimated lifetime risk is $15 \%[22,23,26]$.

\section{The Extrahepatic Reservoir of the $H B V$}

Despite the strong hepatocellular tropism of the virus, HBV was detected in a variety of extrahepatic sites and cell types, including peripheral blood mononuclear cells (PBMCs) [27-29]. Subsequently, it became evident that PBMCs represent a stable long-term extrahepatic reservoir for HBV and that these infected PBMCs may cause reinfection after orthotopic liver transplantation [30-34]. This notion was then further supported by demonstration of HBV replication, active transcription in PBMCs and in vitro infectibility of these cells [35-37], although Kock et al. [163] were not able to detect replication-competent HBV DNA in lymphocytes. Transcriptional activity and the rate of HBV replication may be low enough in these cells for the presence of HBV not to be detected by conventional methods, thus mimicking a HbsAgnegative patient. This was supported by the findings of Roche et al. [38] demonstrating HBV DNA persistence 10 years after liver transplantation despite successful HBIG treatment with or without concomitant antiviral therapy. As a consequence, this extrahepatic reservoir is a current threat for reinfection after liver transplantation and may thus argue for a long-term supply of protective immunoglobulins to prevent graft reinfection [30, 31, 38, 39].

In conclusion, HBV hepatitis is a complex disease, which is reflected in the complicated life cycle and genetic makeup with features that are unique for hepadnaviridae. As there is no available treatment for the elimination of the virus once the infection has established itself, the main goal in national and global anti-hepatitis programs is the prevention of new infections. As mentioned above, this may only be achieved by consequent immunization of newborns to eradicate future reservoirs of the virus, as infection in early childhood predominantly leads to chronic disease and thus to a lifelong source of infection. Therefore, the prevention of infection 'under all circumstances' has to also be a main concern in cases of infants born to HBV-positive mothers and in connection with liver transplantation due to HBV-related liver failure.

\section{$H B V$ Serotypes and Genotypes}

The envelope or surface protein of HBV, the HBs protein or HBsAg is highly immunogenic and induces anti-HBs antibodies. It is antigenically heterogeneous with a common antigen designated a. The 4 variant antigenic determinants are designated $\mathrm{d}, \mathrm{r}$, w and $\mathrm{y}$, with the 2 pairs $\mathrm{d} / \mathrm{y}$ and $\mathrm{w} / \mathrm{r}$ being mutually exclusive, resulting in 4 major antigenic subtypes or phenotypes: adw, ayw, adr, ayr [40, 41]. Subsequently, 4 subdeterminants of w (w1-w4) were identified, resulting in the differentiation of 8 HBs subtypes: adw2, adw4, ayw1, ayw2, ayw3, ayw4, adr, ayr [42]. These subtypes differ in their geographic distribution [43] but not in the clinical features of the corresponding $\mathrm{HBV}$ infection and thus provide useful epidemiological markers, allowing subtle analysis of HBV molecular epidemiology $[1,6,21,44,45]$.

After the first complete HBV DNA sequence was published in 1979 [46], sequencing data from numerous HBV isolates led to the definition of 8 recognized genotypes $\mathrm{A}$ to $\mathrm{H}$ which vary by approximately $8-15 \%$ at the nucleotide level [47-50]. These genotypes show a distinct geographic distribution. Genotype A is prevalent in North America, North-Western Europe and Central Africa. Genotypes B and C are predominantly found in Asia. Genotype D is found worldwide with the highest prevalence in the Mediterranean region. Genotype $\mathrm{E}$ is typically found in Africa, whereas F is typical for the aboriginal population in America and Polynesia. Genotype $G$ has been detected in the USA, France, the UK and Germany, and genotype $\mathrm{H}$ seems to be limited to the native population of Central and South America [164-166]. Some authors have provided data showing that the differences on the nucleotide level might also influence the clinical characteristics of these strains. Analyses of data from several studies indicate that, for example, genotype A was more associated with chronic hepatitis $\mathrm{B}$, whereas genotype $\mathrm{D}$ was predominant in patients with acute disease. The comparison of genotype $\mathrm{B}$ and $\mathrm{C}$ pointed to a more severe disease progression, worse outcome and a higher risk of severe liver dysfunction and HCC for genotype $\mathrm{C}$ than genotype $\mathrm{B}$. The influence of the genotype on the response to antiviral therapy is less clear, but it appears that there are differences among HBV genotypes, e.g. to the response to IFN- $\alpha$, where patients infected with genotypes $\mathrm{A}$ and $\mathrm{B}$ tend to respond better than patients infected with genotypes $\mathrm{C}$ and D. A similar picture seems to emerge for therapy with lamivudine, where patients infected with genotype B seem to have better response rates than patients infected with genotype C. Although the data provided thus far clearly point to differences in severity and progression of the disease depending on the HBV strain, further systematic analysis is needed to substantiate these indications [44, 45, 51, 52, 164-166].

\section{Hepatitis B: The Virus}

HBV belongs to the family of hepadnaviridae which infect birds (e.g. ducks), mammals (North American woodchuck, squirrels) and primates and consists of 2 subgroups: orthohepatnaviridae and avihepadnaviridae. They are characterized by a unique genetic makeup and particularities in their life cycles specific to for these viruses $[1,4,21,53]$. The infec- 
tive virion consists of an outer envelope composed of the $\mathrm{S}$ protein or HBsAg. This envelope encloses the virus DNA associated with the core protein or $\mathrm{HBc}$ antigen ( $\mathrm{HBcAg}$ ). A third protein, $\mathrm{Hbe} \mathrm{Ag}$, is a circulating peptide derived from the core gene which is modified and exported from hepatocytes. The $\mathrm{P}$ protein, the viral polymerase and the HBx-protein complete the set of 5 virus-encoded polypeptides $[1,4$, $21,53]$. The $\mathrm{S}$ protein is synthesized in 3 different forms which differ in size and are termed large, middle and small S protein. They originate from different transcription initiation sites within the $\mathrm{S}$ gene. All 3 proteins share specific antigenic determinants and are responsible for eliciting protective cellular and humoral immunity to the HBsAg. These determinants are the basis for the development of currently available $\mathrm{HBV}$ vaccines. Antibodies to HBsAg which confer protective immunity are detectable in patients who have recovered from acute hepatitis $\mathrm{B}$ and in those immunized with HBV vaccines. They may, however, decrease to a non-detectable level in patients who have fully recovered from the infection [4, 9]. HbcAg which encloses the viral DNA induces a cellular immune response crucial for the killing of infected liver cells. Antibodies to $\mathrm{HBcAg}$ can be detected in all patients who have been exposed to HBV. Anti-HBc antibodies are protective since vaccination was achieved by using the $\mathrm{HBc}$ protein [167]. Their presence alone cannot be used to distinguish acute from chronic infection, and unlike anti-HBs, these antibodies are found in patients with persistent infections as well as in patients who have recovered from a HBV infection $[4,9]$. HBeAg is a circulating protein. It is derived from the core gene, modified and exported from liver cells. It serves as a marker of active viral replication. It is thought that this protein might serve as a tolerogen, as some authors associate the presence of $\mathrm{HbeAg}$ with a diminished immune response [52, 54-56]. Generally, $\mathrm{HBeAg}$ is only detected in persons who also are positive for circulating serum HBV DNA, the most predictable indicator for active viral replication. A fourth protein, the $\mathrm{P}$ protein, is the viral polymerase which contains reverse transcriptase functions. The properties of this enzyme are discussed below. The fifth protein encoded by the HBV genome is the HBx protein, a polypeptide of 154 amino acids. Expression of full-length $\mathrm{HBx}$ protein is important for in vivo infectivity [57]. It acts as a transcriptional activator of several viral and cellular promoters through direct interaction with cellular transcription factors and is also involved in the activation of signal transduction cascades $[51,52]$. Indications are provided by some authors that the HBx protein might play a role in the development of HBV-mediated carcinogenesis and thus HCC [58]. The mechanisms by which the $\mathrm{HBx}$ protein is involved in HCC development are unknown, but HBx-mediated transcriptional transactivation, its binding to the tumor suppressor p53 and deregulation of cell cycle checkpoints indicate an alteration in cellular gene expression and thus a contribution to hepatocyte transformation [52, 59-62].
The viral DNA, called RC DNA (relaxed circular DNA molecule), is partially double stranded, arranged in a circular structure but not covalently closed. The genome size is about 3,200 base pairs and contains 4 open reading frames (ORFs) which are overlapping (see below) and encode 4 protein families. Both strands differ in length thus creating gaps in the circular structure. At the $5^{\prime}$ end of the short plus strand, a ribooligonucleotide is covalently attached which serves as primer in the initial replication steps. At the $5^{\prime}$ end of the minus strand, the viral polymerase is linked covalently to the DNA strand, a feature unique to the hepadnaviridae [51, 63, 64].

The life cycle of the virus starts with the attachment of the virus particle to the surface of hepatocytes by binding to a yet unidentified receptor. The pre-S1 region (amino acids 21-47) of the large $S$ protein is essential for hepatocyte entry $[52,65$, $66]$. Inside the cell, the virion is disassembled, and core particles are then transported to the nucleus where the viral DNA is repaired to form a covalently closed circle, the cccDNA, and viral DNA replication is initiated. Unlike the subsequent steps, this process of attachment, incorporation, disassembly and nuclear transport is not yet fully understood [51, 63, 64]. The cccDNA serves as a template for viral DNA replication as well as synthesis of viral RNAs [51, 52, 64]. The majority of the cccDNA molecules are then (after their synthesis) associated with histones to form a minichromosome in a quasichromatin (nucleosome) structure [67-69] which is assumed to favor stable propagation in the hepatocyte even through cellular divisions, thus, in addition to cccDNA replication, also accounting for viral persistence [70-73]. It is assumed that cccDNA formation is performed by the cellular machinery since the viral polymerase is not required for this process [72]. Since the process of cccDNA formation is unique for the hepadnaviridae, it may serve as a target for drug development $[69,73]$. However, the use of this process as a drug target may have the disadvantage that cccDNA formation is performed by cellular proteins. After viral DNA replication, transcription of the various viral RNAs is initiated from the minichromosomes by using the host cell RNA polymerase II [74]. This transcription is a highly orchestrated process producing several RNA species with distinct functions. In the first step, genomic and subgenomic RNAs are transcribed from the minichromosomes. The subgenomic RNAs function as mRNA for the translation of the envelope (HBs) and $\mathrm{X}$ proteins only. This translation occurs at the rough endoplasmic reticulum (ER), and the $3 \mathrm{HBs}$ species are translocated into the intermediate compartment where they assemble to form a pre-envelope structure. The 2 genomic RNAs are longer than genomic length. Due to different starting points of transcription, 2 distinct RNAs of about $3.5 \mathrm{kB}$ are produced which encode the pre-C, core and pol ORF. The longer RNA (start of transcription at nucleotide 1,785) is responsible for translation of the pre-C/C ORF producing the soluble form of the $\mathrm{HBc}$ protein, the HBeAG. The second genomic RNA, the pregenomic RNA (start of transcription at nu- 
cleotide 1,818) is responsible for translation of the core protein $(\mathrm{HBcAg})$ and the viral polymerase. In addition, this pregenomic RNA species serves as template for reverse transcription of the viral minus DNA strand after encapsidation [75]. Since the rather small HBV genome of $3.2 \mathrm{~kb}$ has only limited coding capacity, the viral RNAs are synthesized from frame-shifted overlapping ORFs [51, 52, 64, 76, 77]. The HBc protein which is synthesized in the cytosol assembles independent of the HBs proteins into pre-core structures. These structures associate with mature pregenomic RNA species to form subviral core particles by an encapsidation-like process. Once the pregenomic RNA is encapsidated, it associates with the viral polymerase, a multifunctional enzyme. This enzyme then undergoes conformational changes and initiates reverse transcription within the pre-core particles. In a highly complex process which also requires accessory cellular proteins the negative DNA strand is synthesized, followed by synthesis of the complementary plus DNA strand which is also performed by the viral polymerase. At the end of this process, the mature, partially double stranded DNA genome of HBV (RC DNA) is formed within the nucleocapsid with the polymerase protein covalently attached to the HBV RC DNA. Details of this highly complex mechanism are reviewed in [4, 51, 52, 64, 72, 73] and references therein.

This process of viral DNA replication via an RNA intermediate and reverse transcription is unique for the hepadnaviridae which makes it a prime target for antiviral drug development as discussed below. The assembly of mature nucleocapsids containing full-length RC DNA occurs in the cytosol. They are then transported to the golgi apparatus, where they are incorporated into the preformed envelope structures made by the 3 HBs species. Once this multistep process is completed, the newly formed mature virions are then secreted to the cell surface via the constitutive pathway of secretion and subsequently released from the cell surface in a non-cytolytic manner [64, 78, 79]. The 3 HBs proteins have distinct and essential functions during morphogenesis and secretion, which was shown by analysis of mutant strains which were replication-competent but showed deficiencies in maturation and secretion [51, 80, 81].

\section{HBV Mutants}

Knowledge of HBV mutants arose from the development of vaccines and treatments against hepatitis B. For each treatment/vaccine developed, thus far resistant strains arose. The resistance could in large be attributed to specific mutations or genetic changes which in turn has led to further understanding of the molecular biology of the virus and further research towards treatment. Three major lines of prophylaxis and therapy can be summarized: i) vaccination; ii) treatment with HBIG or interferon; iii) drugs inhibiting specific steps in the life cycle of the virus, e.g. virostatic drugs.
One has to bear in mind that each therapeutic approach exerts a selective pressure on the corresponding pathogen to evade these constrains by e.g. mutations which will allow the pathogen to survive under the new conditions. Silent mutations which until then were undetected may now become the predominant variant since they allow survival under new therapeutic constraints. As with a lot of viruses and bacteria, each new approach for eradication has produced resistant genotypes, thus reflecting the genetic variability and plasticity of microorganisms, with the spread of resistance to antibiotics for the treatment of bacterial infections being a prime example for this dilemma. With the development of each new treatment or drug, one has to be aware of this problem, even in the case of viruses with genomes as small as that of the hepadnaviridae.

\section{Vaccination Escape Mutants}

Most currently available hepatitis B vaccines are based on cross-protecting epitopes of the $\mathrm{S}$ antigen, predominantly the a epitope. During a study on the immunogenicity and efficacy of hepatitis B vaccines in Italy, it was observed that some patients who had mounted a successful immune response following vaccination (anti-HBs-positive) subsequently became infected with HBV. Molecular analysis of these virus variants by sequencing their $\mathrm{S}$ gene revealed a distinct mutation within the a epitope resulting in an amino acid replacement from glycine to arginine at amino acid position 145 . This point mutation was subsequently detected in isolates from resistant virus mutants worldwide [82-84]. The region in which this mutation occurred, the a epitope of HBs, is an important epitope for the binding of vaccine-induced neutralizing antibodies. It was shown that antibodies of this specificity were no longer able to bind to this region in the mutant virus, thus failing to efficiently neutralize the mutant virus. Since this mutant virus replicates at a normal rate, it was implied that the mutation in the $\mathrm{S}$ protein does not affect the overall efficiency of the binding of virions to the hepatocyte $[8,85]$. Since these initial reports, several types of vaccination escape mutant strains were described. Initial fears that such mutants might become the predominant strains in a population and thus could pose a potential threat to vaccination have so far not proven true. In addition, Ogata et al. [168] showed that licensed recombinant hepatitis B vaccines could protect chimpanzees against infection with such an S gene HBV mutant (G145R) at amino acid position 145. However, close monitoring of the distribution and prevalence of these and especially of new strains should be maintained to minimize the risk of HBV outbreaks [85-89]. Further characterization of the immune response towards epitopes of the $\mathrm{S}$ protein showed that failure to respond to vaccination may also exist at the T-cell level [90]. In addition, such mutations in the $\mathrm{S}$ gene may also affect the polymerase protein and its function because of the overlapping reading frames for the surface and the polymerase protein (see below) [91]. 


\section{HBIG Resistance Mutants}

During treatment of liver transplant patients with HBIG, escape mutations were detected in a number of cases. Most isolates contained the same glycine to arginine shift as observed in the above mentioned vaccination escape mutants. This observation also confirms the finding that changes in the a epitope of the $\mathrm{S}$ protein allows the virus to evade antibody-mediated selective pressure [91-97]. The average overall reinfection rate under HBIG monotherapy ranges from 20 to $35 \%$. Different rates were observed according to the treatment protocol (high vs. low dose), the clinical status of the patient, superinfection with hepatitis D virus and most importantly the virus load and replication status before transplantation [23]. HBV reinfection during the first 6 months after transplantation is usually related to inadequate HBIG levels in patients with a high viral load and/or active viral replication before transplantation, whereas late recurrence is mostly attributed to HBIG escape mutants $[23,94,96]$.

\section{Polymerase Mutations}

The understanding of the unique features of viral DNA replication in hepadnaviridae via an RNA intermediate using reverse transcription has led to the development of several antiviral drugs aimed at inhibiting the HBV polymerase. Since retroviruses also use reverse transcriptase during their life cycle, most drugs which are now used and tested against HBV are derived from retroviral research and were initially developed as anti-HIV therapy. These substances are nucleoside analogues which block the active site for reverse transcription of the enzyme. Several molecules have been investigated, and among the first substances to be released as an antiviral drug was lamivudine, an enantiomer of 3'-thiacytidine. This drug showed significant reduction in viral replication, thus reducing the viral load to a non-detectable level [98]. However, shortly after this drug was widely used in hepatitis B treatment, including liver transplant patients, often fulminant cases of recurrence of viral replication were reported [99-107]. Analysis of the corresponding HBV strains revealed a mutation in the YMDD (Tyr-Met-Asp-Asp) motif of the polymerase protein located in domain $\mathrm{C}$ of the protein $[52,108,109]$. Numerous reports on lamivudine-resistant HBV strains have been published since [23, 110-116].

Although, compared to the wild type, strains with a single YMDD mutation have a markedly reduced replication rate, they become the clinically dominant viral species after only a few months of lamivudine treatment [52, 100, 109, 115-119], with the possible consequence of exacerbation of liver disease and graft failure in transplant patients, as described above. If the selective pressure of lamivudine is sustained, these YMDD mutants may regain their full replicating capacity by compensatory mutations, leading to fulminant progression of the infection $[52,115,116,119,120-123]$. Lamivudine resis- tance is selected in approximately $14-32 \%$ of patients per year of therapy. More importantly, the prevalence of such mutations rises to approximately $70 \%$ after 4 years of treatment, with $100 \%$ of lamivudine resistance observed in some studies after several years of lamivudine monotherapy. Similar results were observed with famciclovir, another nucleoside analogue [23, 110, 112-114, 116, 124-128]. With regard to reinfection prophylaxis after liver transplantation, combination therapy with lamivudine and HBIG was shown to significantly reduce the reinfection rate to almost $0 \%$ in patients who were $\mathrm{HBV}$ negative at the time of transplantation and $10 \%$ in patients showing viral replication at this time, and is currently the state of the art protocol for prevention of graft reinfection $[23,126$, 129-138].

A resistant strain has also been identified for one of the most recently approved drugs of the nucleoside analogue family, adefovir dipivoxil [139], which is now widely used to replace lamivudine in patients with lamivudine-resistant HBV strains [112, 113, 116, 140-143]. Molecular and biochemical analysis of this strain showed that resistance was due to a mutation in the polymerase gene conferring resistance to adefovir dipivoxil. The mutation was identified by DNA sequencing and was shown to be not identical with the YMDD mutant strains, still susceptible to lamivudine and located in domain D of the HBV polymerase [139]. Another report of adefovir resistance which has been published since [144], describes a case of particular interest, since this strain first developed lamivudine resistance with a viral breakthrough under lamivudine therapy. The patient was then switched to adefovir, and lamivudine was discontinued. After the outgrowth of an adefovir-resistant strain, lamivudine was reintroduced while adefovir was maintained. Analysis of samples during the course of treatment revealed that after initiation of adefovir without lamivudine the lamivudine mutation reverted back to wild type followed by subsequent selection of adefovir resistance and regained susceptibility to lamivudine. It would therefore be important to elucidate whether these 2 distinct types of resistance are mutually exclusive or whether corresponding double mutations will be observed during a combination therapy with adefovir and lamivudine, with obvious consequences for such combination therapies [145].

\section{Double Mutants}

As described above, each antiviral agent or therapy has elicited specific resistance mutants, and combination therapy with e.g. HBIG and lamivudine was able to drastically reduce the incidences of reinfection. However, in the case of lamivudine resistance, compensatory mutants restoring replication fitness have been described which can be regarded as double mutants. Sequence information about the YMDD mutants revealed that due to the overlapping reading frames for the polymerase and the HBs protein, mutations in the YMDD 
motif also affect the HBs coding region. It was speculated that due to such mutations, the antigenicity of the a determinant of the HBs protein might be altered, thus leading to double mutants with HBIG and lamivudine resistance. Furthermore, it was speculated that a sequential or a combination therapy with HBIG and lamivudine would produce the corresponding double mutations. Unfortunately, these predictions were confirmed by isolation of several double mutant strains [104, 106, 122, 123, 146-149]. Taking these findings into account, it can be stated that for every given antiviral agent or therapy resistance can be expected, which calls for close monitoring of patients under such treatment.

\section{Conclusion}

In this brief overview of the biology of HBV we showed that an effective therapy for hepatitis B resulting in complete elimination of the virus is still not available. The only way to prevent new infections and spreading of the disease is strict vaccination of newborns to achieve immunity across the entire population. Current prophylactic measures, such as HBIG, nucleoside analogues and vaccines, induce the outgrowth of escape mutants when used as monotherapy. Even with current combination therapies, double mutations are being detected, with the fatal potential of spreading within a population [150].

Despite the rather small genome size of $3.2 \mathrm{~kb}$ with overlapping reading frames, the HBV genome is capable of accommodating a variety of mutations to escape the selective pressure of current treatments. This may be made possible by 2 features of the HBV genome: the high mutation rate and the vast amount of virions produced in the phase of active replication. The mutation frequency for $\mathrm{HBV}$ is estimated to be approximately $1.4-3.2 \times 10^{-5}$ nucleotide substitutions per site and year, which is approximately 10-fold higher than for other DNA viruses $[52,151]$. This can be explained by the re- verse transcriptase function of the HBV polymerase which lacks a proofreading function [52]. In addition, the enormous viral replication rate leading to peak viral loads of $10^{10}$ virions/ml serum and an estimated half-life of the serum HBV pool of about 1-2 days lead to an estimated daily peak rate of de novo HBV production of up to $10^{11}[52,152]$ and even $10^{13}$ virions [153]. These high viral loads and turnover rates coupled with the poor replication fidelity may account for a high prevalence of mutant HBV and thus an extended HBV quasispecies pool at any given time during active replication. The estimated daily peak rate of de novo HBV production led to the assumption that at the time of maximum viral replication every possible single and most double mutations would be produced each day [153]. The vast majority of these mutants will go unnoticed since they may not be as replication-competent as the wild-type virus. However, if a certain selective pressure is applied, as is the case with antiviral treatments, such resistant mutants may become the predominant species in numbers that allow for the selection of compensatory mutants which in turn may restore wild-type replication rates leading to fulminant outbreaks of the disease under therapies as described above. Most resistant HBV strains with either single or compensatory mutations were identified after or during monotherapy with one antiviral drug or treatment. Hence, in order to achieve full control of viral replication, a combination therapy aiming at different targets may be advisable and even necessary in order to raise the selective pressure to a level which can no longer be compensated by the HBV genome [20, 110, 116, 134, 154-161]. However, since even with current combination therapies double mutations are being detected with the potential of spreading in a population [150], close monitoring of such treatment programs is essential to avoid the emergence and spread of truly multiresistant HBV strains, similar to multiple resistance against antibiotics with its known set-backs in the treatment of bacterial infections.

\section{References}

1 WHO Department of Communicable Disease Surveillance and Response, WHO/CDS/CSR/LYO/ 2002.2: Hepatitis B 2002; http://www.who.int/csr/resources/publications/hepatitis/WHO_CDS_CSR_L YO_2002_2/en/

2 Shapiro CN: Transmission of hepatitis viruses. Ann Intern Med 1994;120:82-4.

-3 Lee WM: Hepatitis B virus infection. N Engl J Med 1997;337:1733-45.

4 Hollinger FB, Liang TJ: Hepatitis B virus; in Knipe DM, Howley PM (eds): Fields Virology, 4th ed. Philadelphia, Lippincott Williams and Wilkins, 2001, pp 2971-3036.

5 Blumberg BS, Alter HJ, Visnich S: A new antigen in leukemia sera. JAMA 1965;191:541-6.

6 Mahoney FJ, Kane M: Hepatitis B vaccine; in Plotkin SA, Orenstein WA (eds): Vaccines, 3rd ed. Philadelphia, W.B. Saunders, 1999, pp 158-182.
7 World Health Organization: Introduction of Hepatitis B Vaccine into Childhood Immunization Services. Geneva, WHO, 2001 (unpublished document, $\mathrm{WHO} / \mathrm{V}$ and $\mathrm{B} / 01.31$ available on request from the Department of Vaccines and Biologicals, World Health Organization, 1211 Geneva 27, Switzerland)

8 Zuckerman AJ: Hepatitis viruses; in Baron S (ed): Medical Microbiology, 4th ed. The University of Texas Medical Branch at Galveston, 1996, pp 849-863.

9 Gitlin N: Hepatitis B: diagnosis, prevention, and treatment. Clin Chem 1997;43:1500-1506.

10 Alter MJ, Hadler SC, Margolis HS, Alexander WJ, Hu PY, Judson FN, Mares A, Miller JK, Moyer LA: The changing epidemiology of hepatitis B in the United States. Need for alternative vaccination strategies. JAMA 1990;263:1218-1222.
11 Shapiro CN: Epidemiology of hepatitis B. Pediatr Infect Dis J 1993;12:433-7.

12 Huang K, Lin S: Nationwide vaccination: a success story in Taiwan. Vaccine 2000;18( suppl 1):S35-8.

13 Zanetti AR, Dentico P, Del Vecchio Blanco C, Sagnelli E, Villa E, Ferroni P, Bergamini F: Multicenter trial on the efficacy of HBIG and vaccine in preventing perinatal hepatitis B. Final report. J Med Virol 1986;18:327-34.

14 Wong VC, Ip HM, Reesink HW, Lelie PN, Reerink-Brongers EE, Yeung CY, Ma HK: Prevention of the HBsAg carrier state in newborn infants of mothers who are chronic carriers of HBsAg and HBeAg by administration of hepatitis- $B$ vaccine and hepatitis-B immunoglobulin. Double-blind randomised placebo-controlled study. Lancet 1984;i:921-6.

15 Department of Health: Public health in Taiwan, Republic of China. The Executive Yuan 1998;2: 57-9. 
16 Da Villa G: Rationale for the infant and adolescent vaccination programmes in Italy. Vaccine 2000;18:31-34

17 Da Villa G, Picciottoc L, Elia S, Peluso F, Montanaro F, Maisto T: Hepatitis B vaccination: universal vaccination of newborn babies and children at 12 years of age versus high risk groups. A comparison in the field. Vaccine 1995;13:1240-3.

18 Kane MA: Status of hepatitis B immunization programmes in 1998. Vaccine 1998;16(suppl):S104-8.

19 Chisari FV, Ferrari C: Hepatitis B virus immunopathogenesis. Annu Rev Immunol 1995;13: 29-60.

20 Lok AS: Hepatitis B infection: pathogenesis and management. J Hepatol 2000;32(1 suppl):89-97.

21 Robinson WS: Hepatitis B virus and hepatitis D virus; in Mandell GL, Bennett JE, Dolin R (eds): Principles and Practice of Infectious Diseases, 4th ed. New York, Churchill Livingstone, 1995, pp 1406-1439.

22 Lok AS, McMahon BJ: Chronic hepatitis B. Hepatology 2001;34:1225-41.

23 Lok AS: Prevention of recurrent hepatitis B postliver transplantation. Liver Transpl 2002;8(10 suppl 1):S67-73.

-24 McMahon BJ, Alward WL, Hall DB, Heyward WL, Bender TR, Francis DP, Maynard JE: Acute hepatitis $\mathrm{B}$ virus infection: relation of age to the clinical expression of disease and subsequent development of the carrier state. J Infect Dis 1985 151:599-603.

25 Margolis HS, Alter MJ, Hadler SC: Hepatitis B: evolving epidemiology and implications for control. Semin Liver Dis 1991;11:84-92.

26 Beasley RP: Hepatitis B virus. The major etiology of hepatocellular carcinoma. Cancer 1988;61: 1942-56.

-27 Yoffe B, Burns DK, Bhatt HS, Combes B: Extrahepatic hepatitis B virus DNA sequences in patients with acute hepatitis B infection. Hepatology 1990;12:187-92.

28 Lamelin JP, Trepo C: The hepatitis B virus and the peripheral blood mononuclear cells: a brief review. J Hepatol 1990;10:120-4.

29 Mason A, Wick M, White H, Perrillo R: Hepatitis $\mathrm{B}$ virus replication in diverse cell types during chronic hepatitis B virus infection. Hepatology 1993;18:781-9.

-30 Feray C, Zignego AL, Samuel D, Bismuth A, Reynes M, Tiollais P, Bismuth H, Brechot C: Persistent hepatitis $\mathrm{B}$ virus infection of mononuclear blood cells without concomitant liver infection. The liver transplantation model. Transplantation 1990;49:1155-8.

31 Lamelin JP, Zoulim F, Trepo C: Lymphotropism of hepatitis B and C viruses: an update and a newcomer. Int J Clin Lab Res 1995;25:1-6.

\32 Brind A, Jiang J, Samuel D, Gigou M, Feray C, Brechot C, Kremsdorf D: Evidence for selection of hepatitis B mutants after liver transplantation through peripheral blood mononuclear cell infection. J Hepatol 1997;26:228-35.

\33 Roche B, Samuel D, Gigou M, Feray C, Virot V, Schmets L, David MF, Arulnaden JL, Bismuth A, Reynes M, Bismuth H: De novo and apparent de novo hepatitis B virus infection after liver transplantation. J Hepatol 1997; 26:517-26.

>34 Trippler M, Meyer zum Buschenfelde KH, Gerken G: HBV viral load within subpopulations of peripheral blood mononuclear cells in HBV infection using limiting dilution PCR. J Virol Methods 1999; 78:129-47.
35 Stoll-Becker S, Repp R, Glebe D, Schaefer S, Kreuder J, Kann M, Lampert F, Gerlich WH: Transcription of hepatitis B virus in peripheral blood mononuclear cells from persistently infected patients. J Virol 1997;71:5399-407.

36 Cabrerizo M, Bartolome J, Caramelo C, Barril G, Carreno V: Molecular analysis of hepatitis B virus DNA in serum and peripheral blood mononuclear cells from hepatitis B surface antigen-negative cases. Hepatology 2000;32:116-23.

37 Cabrerizo M, Bartolome J, Carreno V: In vitro infection of human peripheral blood mononuclear cells by a defective hepatitis B virus with a deletion in the PreS1 region of the viral genome. J Viral Hepat 2002;9:265-71.

38 Roche B, Feray C, Gigou M, Roque-Afonso AM, Arulnaden JL, Delvart V, Dussaix E, Guettier C, Bismuth H, Samuel D: HBV DNA persistence 10 years after liver transplantation despite successful anti-HBS passive immunoprophylaxis. Hepatology 2003;38:86-95.

39 Repp R, Mance A, Bertram U, Niemann H, Gerlich WH, Lampert F: Persistent hepatitis B virus replication in mononuclear blood cells as a source of reinfection of liver transplants. Transplantation 1991;52:935.

40 Le Bouvier GL: The heterogeneity of Australia antigen. J Infect Dis 1971;123:671-5.

41 Bancroft WH, Mundon FK, Russell PK: Detection of additional antigenic determinants of hepatitis B antigen. J Immunol 1972;109:842-8.

42 Courouce AM, Drouet J, Muller JY: Australia antigen subtypes identification. Results. Bibl Haematol 1976;42:89-127.

43 Courouce-Pauty AM, Plancon A, Soulier JP: Distribution of HBsAg subtypes in the world. Vox Sang 1983;44:197-211.

44 Magnius LO, Norder H: Subtypes, genotypes and molecular epidemiology of the hepatitis B virus as reflected by sequence variability of the S-gene intervirology 1995;38:24-34.

45 Pumpens P, Grens E, Nassal M: Molecular epidemiology and immunology of hepatitis B virus infection - an update. Intervirology 2002;45:218-32.

46 Galibert F, Mandart E, Fitoussi F, Tiollais P, Charnay P: Nucleotide sequence of the hepatitis B virus genome (subtype ayw) cloned in E. coli. Nature 1979:281:646-50

47 Okamoto H, Tsuda F, Sakugawa H, Sastrosoewignjo RI, Imai M, Miyakawa Y, Mayumi M: Typing hepatitis B virus by homology in nucleotide sequence: comparison of surface antigen subtypes. J Gen Virol 1988;69(Pt 10):2575-83.

48 Norder H, Hammas B, Lofdahl S, Courouce AM, Magnius LO: Comparison of the amino acid sequences of nine different serotypes of hepatitis B surface antigen and genomic classification of the corresponding hepatitis B virus strains. J Gen Virol 1992;73(Pt 5):1201-8.

49 Stuyver L, de Gendt S, van Geyt C, Zoulim F, Fried M, Schinazi RF, Rossau R: A new genotype of hepatitis B virus: complete genome and phylogenetic relatedness. J Gen Virol 2000;81(Pt 1): 67-74.

50 Kao JH: Hepatitis B viral genotypes: clinical relevance and molecular characteristics. J Gastroenterol Hepatol 2002;17:643-50.

51 Kann M, Gerlich W: Hepadnaviridae: structure and molecular virology; in Zuckerman A. Thomas H (eds): Viral Hepatitis. London, Churchill Livingstone, 1998, pp 77-105.

52 Locarnini S, McMillan J, Bartholomeusz A: The hepatitis B virus and common mutants. Semin Liver Dis 2003;23:5-20.
Robinson WS: Molecular events in the pathogenesis of hepadnavirus-associated hepatocellular carcinoma. Annu Rev Med 1994;45:297-323.

54 Milich DR, Jones JE, Hughes JL, Price J, Raney AK, McLachlan A: Is a function of the secreted hepatitis B e antigen to induce immunologic tolerance in utero? Proc Natl Acad Sci U S A 1990;87: 6599-603.

55 Milich DR, Schodel F, Hughes JL, Jones JE, Peterson DL: The hepatitis B virus core and e antigens elicit different Th cell subsets: antigen structure can affect Th cell phenotype. J Virol 1997;71: 2192-201.

56 Milich DR: Influence of T-helper cell subsets and crossregulation in hepatitis B virus infection. J Viral Hepat 1997;4(suppl 2):48-59.

57 Zoulim F, Saputelli J, Seeger C: Woodchuck hepatitis virus $\times$ protein is required for viral infection in vivo. J Virol 1994;68:2026-30.

58 Koike K: Hepatitis B virus HBx gene and hepatocarcinogenesis. Intervirology 1995;38:134-42.

59 Rossner MT: Hepatitis B virus X-gene product: a promiscuous transcriptional activator. J Med Virol 1992;36:101-17.

60 Wang XW, Forrester K, Yeh H, Feitelson MA, Gu JR, Harris CC: Hepatitis B virus X protein inhibits p53 sequence-specific DNA binding, transcriptional activity, and association with transcription factor ERCC3. Proc Natl Acad Sci U S A 1994;91: 2230-4.

61 Wang XW, Gibson MK, Vermeulen W, Yeh H, Forrester K, Sturzbecher HW, Hoeijmakers JH, Harris CC: Abrogation of p53-induced apoptosis by the hepatitis B virus X gene. Cancer Res 1995; 55:6012-6.

62 Truant R, Antunovic J, Greenblatt J, Prives C, Cromlish JA: Direct interaction of the hepatitis B virus $\mathrm{HBx}$ protein with $\mathrm{p} 53$ leads to inhibition by HBx of p53 response element-directed transactivation. J Virol 1995;69:1851-9.

63 Will H, Reiser W, Weimer T, Pfaff E, Buscher M Sprengel R, Cattaneo R, Schaller H: Replication strategy of human hepatitis B virus. J Virol 1987; 61:904-11.

64 Ganem D, Schneider R: Hepadnaviridae: the viruses and their replication: in Knipe DM, Howley PM (eds): Fields Virology, vol. 2, 4th ed Philadelphia, Lippcott-Raven, 2001, pp 2923-70.

65 Neurath AR, Kent SB, Strick N, Parker K: Identification and chemical synthesis of a host cell receptor binding site on hepatitis B virus. Cell 1986;46: 429-36.

66 Bruss V, Hagelstein J, Gerhardt E, Galle PR Myristylation of the large surface protein is required for hepatitis B virus in vitro infectivity. Virology 1996;218:396-9.

67 Bock CT, Schranz P, Schroder CH, Zentgraf H Hepatitis B virus genome is organized into nucleosomes in the nucleus of the infected cell. Virus Genes 1994;8:215-29.

68 Newbold JE, Xin H, Tencza M, Sherman G, Dean J, Bowden S, Locarnini S: The covalently closed duplex form of the hepadnavirus genome exists in situ as a heterogeneous population of viral minichromosomes. J Virol 1995;69:3350-7.

69 Bock CT, Schwinn S, Locarnini S, Fyfe J, Manns MP, Trautwein C, Zentgraf H: Structural organization of the hepatitis B virus minichromosome. J Mol Biol 2001;307:183-96.

70 Dean J, Bowden S, Locarnini S: Reversion of duck hepatitis B virus DNA replication in vivo following cessation of treatment with the nucleoside analogue ganciclovir Antiviral Res 1995;27:171-8. 
71 Dandri M, Burda MR, Will H, Petersen J: Increased hepatocyte turnover and inhibition of woodchuck hepatitis B virus replication by adefovir in vitro do not lead to reduction of the closed circular DNA. Hepatology 2000;32:139-46.

72 Seeger C, Mason WS: Hepatitis B virus biology. Microbiol Mol Biol Rev 2000;64:51-68.

73 Feld J, Locarnini S: Antiviral therapy for hepatitis B virus infections: new targets and technical challenges. J Clin Virol 2002;25:267-83.

74 Tavis JE: The replication strategy of the hepadnaviruses. Viral Hep Rev 1996;2:205-18.

75 Summers J, Mason WS: Replication of the genome of a hepatitis B-like virus by reverse transcription of an RNA intermediate. Cell 1982;29:403-15.

76 Mandart E, Kay A, Galibert F: Nucleotide sequence of a cloned duck hepatitis B virus genome: comparison with woodchuck and human hepatitis B virus sequences. J Virol 1984;49:782-92.

77 Sprengel R, Kuhn C, Will H, Schaller H: Comparative sequence analysis of duck and human hepatitis B virus genomes. J Med Virol 1985;15:323-33.

78 Eckhardt SG, Milich DR, McLachlan A: Hepatitis $B$ virus core antigen has two nuclear localization sequences in the arginine-rich carboxyl terminus. J Virol 1991;65:575-82.

79 Ganem D: Assembly of hepadnaviral virions and subviral particles. Curr Top Microbiol Immunol 1991;168:61-83

80 Bruss V, Thomssen R: Mapping a region of the large envelope protein required for hepatitis B virion maturation. J Virol 1994;68:1643-50.

-81 Bock CT, Tillmann HL, Manns MP, Trautwein C: The pre-S region determines the intracellular localization and appearance of hepatitis B virus. Hepatology 1999;30:517-25.

82 Carman WF, Zanetti AR, Karayiannis P, Waters J, Manzillo G, Tanzi E, Zuckerman AJ, Thomas HC: Vaccine-induced escape mutant of hepatitis B virus. Lancet 1990;336:325-9.

83 Fujii H, Moriyama K, Sakamoto N, Kondo T, Yasuda K, Hiraizumi Y, Yamazaki M, Sakaki Y, Okochi K, Nakajima E: Gly145 to Arg substitution in HBs antigen of immune escape mutant of hepatitis B virus. Biochem Biophys Res Commun 1992;184:1152-7.

84 Waters JA, Kennedy M, Voet P, Hauser P, Petre J, Carman W, Thomas HC: Loss of the common 'A' determinant of hepatitis $\mathrm{B}$ surface antigen by a vaccine-induced escape mutant. J Clin Invest 1992; 90:2543-7.

85 Zuckerman AJ: Effect of hepatitis B virus mutants on efficacy of vaccination. Lancet 2000;355:1382 1384.

86 Carman WF: The clinical significance of surface antigen variants of hepatitis B virus. J Viral Hepat 1997; 4(suppl 1):11-20.

87 Wilson JN, Nokes DJ, Carman WF: Current status of HBV vaccine escape variants-a mathematical model of their epidemiology. J Viral Hepat 1998;5 (suppl 2):25-30.

88 Wilson JN, Nokes DJ, Carman WF: The predicted pattern of emergence of vaccine-resistant hepatitis B: a cause for concern? Vaccine 1999;17:973-978.

89 Chen HB, Fang DX, Li FQ, Jing HY, Tan WG, Li SQ: A novel hepatitis B virus mutant with A-to-G at nt551 in the surface antigen gene. World J Gastroenterol 2003;9:304-8.

90 Bauer T, Weinberger K, Jilg W: Variants of two major $\mathrm{T}$ cell epitopes within the hepatitis B surface antigen are not recognized by specific $\mathrm{T}$ helper cells of vaccinated individuals. Hepatology 2002; 35:455-65.
91 Shields PL, Owsianka A, Carman WF, Boxall E, Hubscher SG, Shaw J, O'Donnell K, Elias E, Mutimer DJ: Selection of hepatitis B surface 'escape' mutants during passive immune prophylaxis following liver transplantation: potential impact of genetic changes on polymerase protein function. Gut 1999;45:306-9.

92 Carman WF, Trautwein C, van Deursen FJ, Colman K, Dornan E, McIntyre G, Waters J, Kliem V, Muller R, Thomas HC, Manns MP: Hepatitis B virus envelope variation after transplantation with and without hepatitis B immune globulin prophylaxis. Hepatology 1996;24:489-93.

-93 Trautwein C, Schrem H, Tillmann HL, Kubicka S, Walker D, Boker KH, Maschek HJ, Pichlmayr R, Manns MP: Hepatitis B virus mutations in the pre-S genome before and after liver transplantation. Hepatology 1996;24:482-8.

94 Ghany MG, Ayola B, Villamil FG, Gish RG, Rojter S, Vierling JM, Lok AS: Hepatitis B virus S mutants in liver transplant recipients who were reinfected despite hepatitis B immune globulin prophylaxis. Hepatology 1998;27:213-22.

95 Protzer-Knolle U, Naumann U, Bartenschlager R, Berg T, Hopf U, Meyer zum Buschenfelde KH, Neuhaus P, Gerken G: Hepatitis B virus with antigenically altered hepatitis B surface antigen is selected by high-dose hepatitis B immune globulin after liver transplantation. Hepatology 1998;27: 254-63.

96 Terrault NA, Zhou S, McCory RW, Pruett TL, Lake JR, Roberts JP, Ascher NL, Wright TL: Incidence and clinical consequences of surface and polymerase gene mutations in liver transplant recipients on hepatitis B immunoglobulin. Hepatology 1998;28:555-61.

97 Santantonio T, Gunther S, Sterneck M, Rendina M, Messner M, Launois B, Francavilla A, Pastore G, Will H: Liver graft infection by HBV S-gene mutants in transplant patients receiving long-term HBIg prophylaxis. Hepatogastroenterology 1999; 46:1848-54.

-98 Grellier L, Mutimer D, Ahmed M, Brown D, Burroughs AK, Rolles K, McMaster P, Beranek P, Kennedy F, Kibbler H, McPhillips P, Elias E, Dusheiko G: Lamivudine prophylaxis against reinfection in liver transplantation for hepatitis B cirrhosis. Lancet 1996;348:1212-5.

-99 Tipples GA, Ma MM, Fischer KP, Bain VG, Kneteman NM, Tyrrell DL: Mutation in HBV RNA-dependent DNA polymerase confers resistance to lamivudine in vivo. Hepatology 1996;24: 714-7.

100 De Man RA, Bartholomeusz AI, Niesters HG, Zondervan PE, Locarnini SA: The sequential occurrence of viral mutations in a liver transplant recipient re-infected with hepatitis B: hepatitis B immune globulin escape, famciclovir non-response, followed by lamivudine resistance resulting in graft loss. J Hepatol 1998;29:669-75.

101 Peters MG, Singer G, Howard T, Jacobsmeyer S, Xiong X, Gibbs CS, Lamy P, Murray A: Fulminant hepatic failure resulting from lamivudine-resistant hepatitis B virus in a renal transplant recipient: durable response after orthotopic liver transplantation on adefovir dipivoxil and hepatitis B immune globulin. Transplantation 1999;68:1912-4.

102 Mutimer D, Feraz-Neto BH, Harrison R, O’Donnell K, Shaw J, Cane P, Pillay D: Acute liver graft failure due to emergence of lamivudine resistant hepatitis B virus: rapid resolution during treatment with adefovir. Gut 2001;49:860-3.
103 Bonacini M, Kurz A, Locarnini S, Ayres A, Gibbs C: Fulminant hepatitis B due to a lamivudine-resistant mutant of $\mathrm{HBV}$ in a patient coinfected with HIV. Gastroenterology 2002;122:244-5.

104 Bock CT, Tillmann HL, Torresi J, Klempnauer J, Locarnini S, Manns MP, Trautwein C: Selection of hepatitis $\mathrm{B}$ virus polymerase mutants with enhanced replication by lamivudine treatment after liver transplantation. Gastroenterology 2002;122: 264-73.

105 Wang JH, Lu SN, Lee CM, Lee JF, Chou YP: Fatal hepatic failure after emergence of the hepatitis B virus mutant during lamivudine therapy in a patient with liver cirrhosis. Scand J Gastroenterol 2002;37:366-9.

106 Ayres A, Bartholomeusz A, Lau G, Lam KC, Lee JY, Locarnini S: Lamivudine and famciclovir resistant hepatitis B virus associated with fatal hepatic failure. J Clin Virol 2003;27:111-6.

107 Wiegand J, Tischendorf JJ, Nashan B, Klempnauer J, Flemming P, Niemann P, Rohde P, Manns MP, Trautwein C, Tillmann HL: Severe exacerbation of chronic hepatitis $\mathrm{B}$ after emergence of lamivudine resistance in a cirrhotic patient: immediate switch to adefovir dipivoxil appears to be indicated. Z Gastroenterol 2004;42:15-8.

108 Allen MI, Deslauriers M, Andrews CW, Tipples GA, Walters KA, Tyrrell DL, Brown N, Condreay LD: Identification and characterization of mutations in hepatitis B virus resistant to lamivudine. Lamivudine Clinical Investigation Group. Hepatology 1998;27:1670-7.

109 Stuyver LJ, Locarnini SA, Lok A, Richman DD, Carman WF, Dienstag JL, Schinazi RF: Nomenclature for antiviral-resistant human hepatitis B virus mutations in the polymerase region. Hepatology 2001;33:751-7.

110 Torresi J, Locarnini S: Antiviral chemotherapy for the treatment of hepatitis B virus infections. Gastroenterology 2000;118(2 suppl 1):S83-103.

111 Ben-Ari Z, Mor E, Shapira Z, Tur-Kaspa R Long-term experience with lamivudine therapy for hepatitis B virus infection after liver transplantation. Liver Transpl 2001;7:113-7.

112 Berenguer M, Wright TL: Treatment of recurrence of hepatitis B in transplant patients. J Hepatol 2003; 39(suppl 1):S190-3.

-113 Papatheodoridis GV, Sevastianos V, Burroughs AK: Prevention of and treatment for hepatitis B virus infection after liver transplantation in the nucleoside analogues era. Am J Transplant 2003 3:250-8.

114 Ben-Ari Z, Mor E, Tur-Kaspa R: Experience with lamivudine therapy for hepatitis B virus infection before and after liver transplantation, and review of the literature. J Intern Med 2003;253:544-52.

115 Fontana RJ: Management of patients with decompensated HBV cirrhosis. Semin Liver Dis 2003 Feb;23:89-100.

116 Shaw T, Bowden S, Locarnini S: Rescue therapy for drug resistant hepatitis B: another argument for combination chemotherapy? Gastroenterology 2004;126:343-7.

117 Melegari M, Scaglioni PP, Wands JR: Hepatitis B virus mutants associated with 3TC and famciclovir administration are replication defective. Hepatology 1998;27:628-33.

118 Liaw YF, Chien RN, Yeh CT, Tsai SL, Chu CM Acute exacerbation and hepatitis B virus clearance after emergence of YMDD motif mutation during lamivudine therapy. Hepatology 1999;30: 567-72. 
119 Delaney WE 4th, Yang H, Westland CE, Das K, Arnold E, Gibbs CS, Miller MD, Xiong S: The hepatitis B virus polymerase mutation $\mathrm{rtV} 173 \mathrm{~L}$ is selected during lamivudine therapy and enhances viral replication in vitro. J Virol 2003;77:11833-41.

120 Yeh CT, Chien RN, Chu CM, Liaw YF: Clearance of the original hepatitis B virus YMDD-motif mutants with emergence of distinct lamivudine-resistant mutants during prolonged lamivudine therapy. Hepatology 2000;31:1318-26.

-121 Lok AS, Hussain M, Cursano C, Margotti M, Gramenzi A, Grazi GL, Jovine E, Benardi M, Andreone P: Evolution of hepatitis B virus polymerase gene mutations in hepatitis $\mathrm{B}$ e antigen negative patients receiving lamivudine therapy. Hepatology 2000;32:1145-53.

122 Torresi J: The virological and clinical significance of mutations in the overlapping envelope and polymerase genes of hepatitis B virus. J Clin Virol 2002;25:97-106.

123 Torresi J, Earnest-Silveira L, Deliyannis G, Edgtton K, Zhuang H, Locarnini SA, Fyfe J, Sozzi T, Jackson DC: Reduced antigenicity of the hepatitis $\mathrm{B}$ virus $\mathrm{HBsAg}$ protein arising as a consequence of sequence changes in the overlapping polymerase gene that are selected by lamivudine therapy. Virology 2002;293:305-13.

124 Perrillo RP, Wright T, Rakela J, Levy G, Schiff E Gish R, Martin P, Dienstag J, Adams P, Dickson R, Anschuetz G, Bell S, Condreay L, Brown N: Lamivudine North American Transplant Group. A multicenter United States-Canadian trial to assess lamivudine monotherapy before and after liver transplantation for chronic hepatitis $\mathrm{B}$. Hepatology 2001;33:424-32.

125 Terrault NA: Treatment of recurrent hepatitis B infection in liver transplant recipients. Liver Transpl 2002;8(10 suppl 1):S74-81.

-126 Lok AS, Lai CL, Leung N, Yao GB, Cui ZY, Schiff ER, Dienstag JL, Heathcote EJ, Little NR, Griffiths DA, Gardner SD, Castiglia M: Longterm safety of lamivudine treatment in patients with chronic hepatitis B. Gastroenterology 2003; 125:1714-22.

127 Lai CL, Dienstag J, Schiff E, Leung NW, Atkins M, Hunt C, Brown N, Woessner M, Boehme R, Condreay L: Prevalence and clinical correlates of YMDD variants during lamivudine therapy for patients with chronic hepatitis B. Clin Infect Dis 2003;36:687-96.

-128 Akuta N, Suzuki F, Kobayashi M, Matsuda M, Sato J, Takagi K, Tsubota A, Suzuki Y, Hosaka T, Someya T, Kobayashi M, Saitoh S, Arase Y, Ikeda K, Kumada H: Virological and biochemical relapse according to YMDD motif mutant type during long-term lamivudine monotherapy. J Med Virol 2003;71:504-10.

-129 Han SH, Ofman J, Holt C, King K, Kunder G, Chen P, Dawson S, Goldstein L, Yersiz H, Farmer DG, Ghobrial RM, Busuttil RW, Martin P: An efficacy and cost-effectiveness analysis of combination hepatitis B immune globulin and lamivudine to prevent recurrent hepatitis B after orthotopic liver transplantation compared with hepatitis B immune globulin monotherapy. Liver Transpl 2000;6:741-8.

130 Markowitz JS, Martin P, Conrad AJ, Markmann JF, Seu P, Yersiz H, Goss JA, Schmidt P, Pakrasi A, Artinian L, Murray NG, Imagawa DK, Holt C, Goldstein LI, Stribling R, Busuttil RW: Prophylaxis against hepatitis $B$ recurrence following liver transplantation using combination lamivudine and hepatitis B immune globulin. Hepatology 1998;28:585-9.
131 Yao FY, Osorio RW, Roberts JP, Poordad FF, Briceno MN, Garcia-Kennedy R, Gish RR: Intramuscular hepatitis B immune globulin combined with lamivudine for prophylaxis against hepatitis B recurrence after liver transplantation. Liver Transpl Surg 1999;5:491-6.

132 Yoshida EM, Erb SR, Partovi N, Scudamore CH, Chung SW, Frighetto L, Eggen HJ, Steinbrecher UP: Liver transplantation for chronic hepatitis B infection with the use of combination lamivudine and low-dose hepatitis B immune globulin. Liver Transpl Surg 1999:5:520-5.

133 Angus PW, McCaughan GW, Gane EJ, Crawford DH, Harley H: Combination low-dose hepatitis B immune globulin and lamivudine therapy provides effective prophylaxis against posttransplantation hepatitis B. Liver Transpl 2000;6:429-33.

134 Perrillo RP: Antiviral therapy to prevent and treat hepatitis B virus infection in hepatic allografts. Clin Transplant 2000;14(suppl 2):25-8.

135 Peters MG, Shouval D, Bonham A, Vierling JM, Lok AS: Posttransplantation: future therapies. Semin Liver Dis 2000;20(suppl 1):19-24.

136 Marzano A, Salizzoni M, Debernardi-Venon W, Smedile A, Franchello A, Ciancio A, Gentilcore E, Piantino P, Barbui AM, David E, Negro F, Rizzetto M: Prevention of hepatitis B virus recurrence after liver transplantation in cirrhotic patients treated with lamivudine and passive immunoprophylaxis. J Hepatol 2001;34:903-10.

137 Rosenau J, Bahr MJ, Tillmann HL, Trautwein C, Klempnauer J, Manns MP, Boker KHW: Lamivudine and low-dose hepatitis B immune globulin for prophylaxis of hepatitis B reinfection after liver transplantation possible role of mutations in the YMDD motif prior to transplantation as a risk factor for reinfection. J Hepatol 2001;34:895-902.

138 Rosenau J, Tillmann HL, Bahr MJ, Trautwein C, Boeker KH, Nashan B, Klempnauer J, Manns MP: Successful hepatitis B reinfection prophylaxis with lamivudine and hepatitis B immune globulin in patients with positive HBV-DNA at time of liver transplantation. Transplant Proc 2001;33: 3637-8.

139 Angus P, Vaughan R, Xiong S, Yang H, Delaney W, Gibbs C, Brosgart C, Colledge D, Edwards R, Ayres A, Bartholomeusz A, Locarnini S: Resistance to adefovir dipivoxil therapy associated with the selection of a novel mutation in the HBV polymerase. Gastroenterology 2003;125:292-7.

140 Perrillo R, Schiff E, Yoshida E, Statler A, Hirsch K, Wright T, Gutfreund K, Lamy P, Murray A: Adefovir dipivoxil for the treatment of lamivudine-resistant hepatitis B mutants. Hepatology 2000;32:129-34.

141 Schiff ER, Lai CL, Hadziyannis S, Neuhaus P, Terrault N, Colombo M, Tillmann HL, Samuel D, Zeuzem S, Lilly L, Rendina M, Villeneuve JP, Lama N, James C, Wulfsohn MS, Namini H, Westland C, Xiong S, Choy GS, van Doren S, Fry J, Brosgart CL: Behalf of the Adefovir Dipovoxil Study 435 International Investigators Group. Adefovir dipivoxil therapy for lamivudine-resistant hepatitis B in pre- and post-liver transplantation patients. Hepatology 2003;38:1419-27.

142 Barcena Marugan R, Cid Gomez L, Lopez Serrano P: Use of adefovir in the treatment of the chronic hepatitis B virus infection with resistance to lamivudine. Transplant Proc 2003;35:1841-3.

143 Perrillo R, Hann HW, Mutimer D, Willems B, Leung N, Lee WM, Moorat A, Gardner S, Woessner M, Bourne E, Brosgart CL, Schiff E: Adefovir dipivoxil added to ongoing lamivudine in chronic hepatitis B with YMDD mutant hepatitis B virus. Gastroenterology 2004;126:81-90.
144 Villeneuve JP, Durantel D, Durantel S, Westland C, Xiong S, Brosgart CL, Gibbs CS, Parvaz P, Werle B, Trepo C, Zoulim F: Selection of a hepatitis B virus strain resistant to adefovir in a liver transplantation patient. J Hepatol 2003;39:1085-9.

145 Aloman C, Wands JR: Resistance of HBV to adefovir dipivoxil: a case for combination antiviral therapy? Hepatology 2003;38:1584-7.

146 Tillmann HL, Trautwein C, Bock T, Boker KH, Jackel E, Glowienka M, Oldhafer K, Bruns I, Gauthier J, Condreay LD, Raab HR, Manns MP: Mutational pattern of hepatitis B virus on sequential therapy with famciclovir and lamivudine in patients with hepatitis B virus reinfection occurring under HBIg immunoglobulin after liver transplantation. Hepatology 1999;30:244-56.

147 Mutimer D, Pillay D, Cook P, Ratcliffe D, O'Donnell K, Dowling D, Shaw J, Elias E, Cane PA: Selection of multiresistant hepatitis B virus during sequential nucleoside-analogue therapy. J Infect Dis 2000;181:713-6.

148 Mutimer D: Hepatitis B virus infection: resistance to antiviral agents. J Clin Virol 2001;21:239-42.

149 Torresi J, Earnest-Silveira L, Civitico G, Walters TE, Lewin SR, Fyfe J, Locarnini SA, Manns M Trautwein C, Bock TC: Restoration of replication phenotype of lamivudine-resistant hepatitis B virus mutants by compensatory changes in the 'fingers' subdomain of the viral polymerase selected as a consequence of mutations in the overlapping S gene. Virology 2002;299:88-99.

150 Fontana RJ, Lok AS: Combination of HBIG and lamivudine-resistant mutations: a formula for trouble? Liver Transpl 2002;8:1082-4.

151 Okamoto H, Imai M, Kametani M, Nakamura T, Mayumi M: Genomic heterogeneity of hepatitis B virus in a 54-year-old woman who contracted the infection through materno-fetal transmission. Jpn J Exp Med 1987;57:231-6.

152 Nowak MA, Bonhoeffer S, Hill AM, Boehme R, Thomas HC, McDade H: Viral dynamics in hepatitis B virus infection. Proc Natl Acad Sci U S A 1996;93:4398-402.

153 Whalley SA, Murray JM, Brown D, Webster GJ, Emery VC, Dusheiko GM, Perelson AS: Kinetics of acute hepatitis B virus infection in humans. J Exp Med 2001;193:847-54.

154 Malik AH, Lee WM: Chronic hepatitis B virus in fection: treatment strategies for the next millennium. Ann Intern Med 2000;132:723-31.

155 Seehofer D, Rayes N, Neuhaus R, Berg T, Muller AR, Bechstein WO, Neuhaus P: Antiviral combination therapy for lamivudine-resistant hepatitis B reinfection after liver transplantation. Transp Int 2000; 13(suppl 1):S359-62.

156 Regev A, Schiff ER: Drug therapy for hepatitis B. Adv Intern Med 2001;46:107-35.

157 Wolters LM, Niesters HG, de Man RA: Nucleoside analogues for chronic hepatitis B. Eur J Gastroenterol Hepatol 2001:13:1499-506.

158 Delaney W 4th, Bartholomeusz A, Locarnini SA: Evolving therapies for the treatment of chronic hepatitis B virus infection. Expert Opin Investig Drugs 2002;11:169-87.

159 Lewin S, Walters T, Locarnini S: Hepatitis B treatment: rational combination chemotherapy based on viral kinetic and animal model studies. Antiviral Res 2002;55:381-96.

160 Zoulim F: Treatment of pre- and post-liver transplantation HBV infection: Should we aim at combination therapy? Hepatology 2003;38:1353-5. 
161 Feld J, Lee JY, Locarnini S: New targets and possible new therapeutic approaches in the chemotherapy of chronic hepatitis B. Hepatology 2003;38:545-53.

162 Knutsson M, Kidd-Ljunggren K: Urine from chronic hepatitis B virus carriers: implications for infectivity. J Med Virol 2000;60:17-20.

163 Kock J, Theilmann L, Galle P, Schlicht HJ: Hepatitis B virus nucleic acids associated with human peripheral blood mononuclear cells do not originate from replicating virus. Hepatology 1996; 23:405-13.

164 Verschuere V, Yap PS, Fevery J: Is HBV genotyping of clinical relevance? Acta Gastroenterol Belg 2005;68:233-6.

165 Kramvis A, Kew MC: Relationship of genotypes of hepatitis B virus to mutations, disease progression and response to antiviral therapy. J Viral Hepat 2005;12:456-64.

166 Guettouche T, Hnatyszyn HJ: Chronic hepatitis B and viral genotype: the clinical significance of determining HBV genotypes. Antivir Ther 2005;10: 593-604.

167 Schodel F, Neckermann G, Peterson D, Fuchs K, Fuller S, Will H, Roggendorf M: Immunization with recombinant woodchuck hepatitis virus nucleocapsid antigen or hepatitis B virus nucleocapsid antigen protects woodchucks from woodchuck hepatitis virus infection. Vaccine 1993;11:624-8.

168 Ogata N, Cote PJ, Zanetti AR, Miller RH, Shapiro M, Gerin J, Purcell RH: Licensed recombinant hepatitis $\mathrm{B}$ vaccines protect chimpanzees against infection with the prototype surface gene mutant of hepatitis B virus. Hepatology 1999;30: 779-86. 